\title{
The Effect of Earnings Management Practice on Corporate Borrowing Capacity through Corporate Reputation
}

\author{
Andy Setiawan ${ }^{1}$, Ancella Anitawati Hermawan ${ }^{1 *}$ \\ ${ }^{1}$ Faculty of Economics and Business, Universitas Indonesia, Depok 16424, Indonesia \\ *ancella_hermawan@yahoo.com
}

\begin{abstract}
This research is conducted to determine the association between earnings management practice and corporate borrowing capacity through corporate reputation. Earnings management practice is measured by discretionary accruals based on the Modified Jones Model. Hypotheses are tested using multiple regression analysis and two-stage ordinary least squares for 65 companies listed on the Indonesia Stock Exchange in the period 2012-2013. The results of the research provide empirical evidence that earnings management practice has a significant negative association with corporate reputation, while corporate reputation has a significant positive association with corporate borrowing capacity. The results of this research also show that there is a significant positive association between corporate reputation estimated by earnings management practice and borrowing capacity.
\end{abstract}

Keywords: Earnings Management; Corporate Reputation; Corporate Borrowing Capacity.

\section{INTRODUCTION}

In the current business environment, earnings management has become a strategy by which managers seek to achieve their opportunistic interests. Earnings management is an interesting topic that arises from agency theory ${ }^{1}$ and has prompted much research in the field. Agency theory explains the condition in which the capital owner or principal delegates decision-making authority to other parties, or an agent. It provides a means of understanding why managers do not always act in the best interests of stakeholders and why they might sometimes behave unethically, and also, perhaps, illegally. It is inherent in the relationship that if the agents and principals have different goals, and if agents take actions that are not in the best interests of their principals, the agency problem will arise ${ }^{2}$.

Earnings management is a way for managers to manage reported income and is one of the inherent agency problems that will lower the quality of reported income and lead to the creation of asymmetric information between principal and agent. The motivation for managers to engage in opportunistic earnings management is also explained in the positive accounting theory. Under the positive accounting theory, the gap in the interests between principal and agent, as described in the agency theory, will motivate the agent to undertake opportunistic behavior in the form of earnings management in order to fulfill their personal interest, given that information asymmetry exists ${ }^{3}$.

Earnings management practice, in a sense, makes visible the reported income according to the intention of the managers. It will directly affect the quality of the reported earnings since these will not be as they are supposed to be. The outside parties, including investors and creditors, would not prefer a lower quality of reported earnings. Managers who overly pursue earnings management will be deemed to be not truthful in reporting earnings, and these perceptions can directly affect the manager and the wider corporate reputation, with previous studies ${ }^{4-6}$ having pointed out the negative effect of discretionary accounting practices on corporate reputation. In summary, earnings management will exert a negative impact on corporate reputation.

Companies with a bad reputation tend to have a lower debt capacity. Companies with a higher reputation are perceived as those that perform well and exercise good corporate governance that upholds business ethics. In this sense, corporate reputation can also act as a form of collateral for creditors and banks to grant loans to a company. Thus, the better a company's reputation, the more likely creditors and/or banks are to approve higher loans. Previous research ${ }^{7}$ points out the positive impact of corporate reputation on borrowing capacity. A previous study $^{8}$ looking at 1,415 companies in the United States found that positive corporate reputation can become collateral for banks to grant loans.

The previous findings support the logic of debt as a motivation for managers to practice earnings management. There is also evidence that discretionary accounting practices in earnings management impacts corporate reputation in a negative way. But in contrast to previous findings, another study ${ }^{9}$ suggested that firms may be able to move toward their expected ratings by performing earnings management. It suggested that earnings management practice might not be detected by the rating agency, which as a result may lead to the management adopting a more favorable position to gain an increase in debt ratings. Set in the same exposure of information as the public, it is possible for creditors and banks to overlook the existence of earnings management. 
Deeper research into this subject will thus be conducted in line with this logic, to determine the effect of earnings management on corporate reputation and corporate borrowing capacity. This research is also conducted to determine the effect of corporate reputation on borrowing capacity and the two-stage effect of earnings management on corporate borrowing capacity through corporate reputation.

\section{LITERATURE REVIEW AND HYPOTHESIS DEVELOPMENT}

Earnings management is the practice of using flexibility in accounting rules to improve the apparent profitability of the firm ${ }^{10}$. GAAP also provide firms with considerable discretion with regard to managing their earnings. Earnings management is defined as a choice of accounting policies taken by a manager, or real actions, to affect earnings so as to achieve some specific reported earnings objective ${ }^{1}$. Managers can perform earnings management through both real actions and/or their choice of accounting policies.

Corporate reputation as a perceived representation of a company's corporate history and prospects depends on the information received by the public. The public will use such information to form perceptions of corporate behavior and thus to determine a company's corporate reputation. A previous study ${ }^{5}$ pointed out the negative impact of discretionary accounting practices on the value of companies, their transactions, their reputation, and their corporate image. Previous research ${ }^{6}$ has also found that earnings management practices decrease corporate reputation. Thus, the public will perceive opportunistic earnings management as damaging for corporate reputation.

Based on this logic, a negative relationship is expected between earnings management practices and corporate reputation, with manipulative accounting practice damaging corporate reputation.

H1a: Earnings management practice has a negative association with corporate reputation.

A positive corporate reputation will be perceived as an assurance by the company to act more ethically. Creditors will be inclined to place greater trust in the information reported by a firm with a better reputation. It was pointed out in a previous study ${ }^{8}$ that positive corporate reputation can be used as collateral by banks to grant credit. Another study ${ }^{7}$ also found that corporate reputation has a significant positive effect on corporate borrowing capacity. Any increase in corporate reputation will signal that the company is perceived as being more capable and more trustworthy. Since creditors take notice of information asymmetry, they will consider corporate reputation, along with corporate financial performance, as a deciding factor for granting loans.

H2a: Corporate reputation has a positive association with borrowing capacity.

Earnings management practice as an opportunistic behavior of the manager would not be positively accepted by lenders or banks. Earnings management practice, if detected, would lead to distrust on the part of the banks. Under the pressure of trust, a bank would thus likely demand more collateral for any loans taken by the company.

A previous study ${ }^{11}$ investigated how bank monitoring of borrowers' earnings management behavior found that collateral and loan types are significantly associated with borrowers' earnings management behavior. Based on this, earnings management practice will also directly and negatively affect borrowing capacity.

H3a: Earnings management practices have a negative association with borrowing capacity.

Previous research ${ }^{8}$ found a positive relationship between corporate reputation and borrowing capacity. A higher reputation will serve to increase the collateral for banks. Another study ${ }^{5}$ pointed out that the existence of earnings management practice will decrease corporate reputation. It is thus logical to consider that earnings management practice will also negatively affect borrowing capacity through the mediation of corporate reputation.

H4a: Earnings management practice has a negative association with borrowing capacity through corporate reputation.

\section{RESEARCH METHOD}

The population in this research is all of the companies that were listed on the Indonesian Stock Exchange (IDX) between 2012 and 2013 and listed for Frontier Consulting Group's Corporate Image Award in 2013 and 2014. The use of the Corporate Image Award is lagged by one year in order to capture the effect of the previous year's performance, since the award is presented in the 4th month of each year. The total number of observations in this research is 65 company-years.

This research will use the two-stage ordinary least squares (OLS) method to test the hypotheses. The twostage OLS method is used to determine the indirect effect of earnings management practice on corporate borrowing capacity through corporate reputation. In order to run the two-stage OLS method, two stages of hypothesis testing are performed.

The first stage is to determine the effect of earnings management practices on corporate reputation. In this stage, the independent variable is earnings management practice as represented by discretionary accruals, and the 
dependent variable is corporate reputation index. Other variables employed to control the factors that affect corporate reputation are profitability and company size.

The second stage is to determine the effect of corporate reputation on borrowing capacity. In this second stage, the independent variable is the corporate reputation index estimated from the first stage, and the dependent variable is borrowing capacity as represented by change in bank debt to assets. Other variables are also employed to control the factors that affect borrowing capacity. The control variable is operating cash flow.

$\mathrm{REP}_{\mathrm{it}+1}=\alpha_{0}+\alpha_{1} \mathrm{DACC}_{\mathrm{it}}+\alpha_{2} \mathrm{ROA}_{\mathrm{it}}+\alpha_{3} \mathrm{SIZE}_{\mathrm{it}}+\exists_{\mathrm{it}}$

The second hypothesis $(\mathrm{H} 2 \mathrm{a})$ will be described as follow:

$\Delta \mathrm{BDTA}_{\text {it }}=\alpha_{0}+\alpha_{1} \mathrm{REP}_{\text {it }}+\alpha_{2} \mathrm{CFTA}_{\text {it }}+\ni_{\text {it }}$

The third hypothesis (H3a) will be described as follow:

$\Delta \mathrm{BDTA}_{\mathrm{it}}=\alpha_{0}+\alpha_{1} \mathrm{DACC}_{\mathrm{it}}+\alpha_{2} \mathrm{CFTA}_{\mathrm{it}}+\exists_{\mathrm{it}}$

The fourth hypothesis ( $\mathrm{H} 4 \mathrm{a})$ will be described as follow:

$\Delta \mathrm{BDTA}_{i t}=\alpha_{0}+\alpha_{1}$ REPCAP $_{\text {it }}+\alpha_{2} \mathrm{DACC}_{\mathrm{it}}+\alpha_{3} \mathrm{CFTA}_{\mathrm{it}}+\exists_{\mathrm{it}}$

Where: $i$ represents the company; $t$ represents the time period; $\alpha$ represents estimating parameters; $\exists_{\mathrm{it}}$ represents the error term; REP is corporate reputation index (measured using the corporate image index published by Frontier Consulting Group); REPCAP is estimated value of corporate reputation (estimated by inserting the coefficient of the model with each respective value of the independent variables: REPCAP $=\alpha_{0}+\alpha_{1} \mathrm{DACC}_{\mathrm{it}}+\alpha_{2} \mathrm{ROA}_{\mathrm{it}}+\alpha_{3} \mathrm{SIZE}_{\mathrm{it}}$ $+\exists_{\mathrm{it}}$ ); DACC is discretionary accruals (as measured by the Modified Jones Model); WC is working capital; SIZE is company size (measured by the natural logarithm of total assets); $\triangle \mathrm{BDTA}$ is the change in bank debt to total assets; ROA is return on assets; and CFTA is cash flows from operating activity divided by total assets.

Table 1.Regression Results (Model 1 and 2)

\begin{tabular}{|c|c|c|c|c|c|c|c|}
\hline & \multirow{3}{*}{$\begin{array}{l}\text { Expected } \\
\text { Sign }\end{array}$} & \multicolumn{3}{|c|}{ Model 1 (REP) } & \multicolumn{3}{|c|}{ Model 2 (BDTA) } \\
\hline & & $\begin{array}{l}\text { Unstandardized } \\
\text { Coefficients }\end{array}$ & $\mathrm{t}$ & Sig. & $\begin{array}{l}\text { Unstandardized } \\
\text { Coefficients }\end{array}$ & $t$ & Sig. \\
\hline & & B & & & B & & \\
\hline (Constant) & & -3.257 & $-2.407^{* *}$ & 0.010 & 0.004 & 0.196 & 0.423 \\
\hline DACC & - & -0.215 & $2.805 * * *$ & 0.004 & & & \\
\hline ROA & + & 1.954 & $2.184^{* *}$ & 0.017 & & & \\
\hline SIZE & + & 0.187 & $3.212^{* * *}$ & 0.001 & & & \\
\hline REP & + & & & & 0.029 & $2.162^{* *}$ & 0.017 \\
\hline CFTA & + & & & & -0.413 & $-4.898 * * *$ & 0.000 \\
\hline \multicolumn{2}{|l|}{ R-squared } & \multicolumn{3}{|c|}{0.283} & \multicolumn{3}{|c|}{0.293} \\
\hline \multicolumn{2}{|l|}{ Adjusted R-squared } & \multicolumn{3}{|c|}{0.248} & \multicolumn{3}{|c|}{0.270} \\
\hline \multicolumn{2}{|l|}{ F-statistic } & \multicolumn{3}{|c|}{$8.032^{* * *}$} & \multicolumn{3}{|c|}{$12.819^{* * *}$} \\
\hline \multicolumn{2}{|l|}{ Prob (F-statistic) } & \multicolumn{3}{|c|}{0.000} & \multicolumn{3}{|c|}{0.000} \\
\hline
\end{tabular}

*** Significant at the 0.01 level

** Significant at the 0.05 level

* Significant at the 0.10 level

Source : Data processed with SPSS 23 
Table.2.Regression Results (Model 3 and 4)

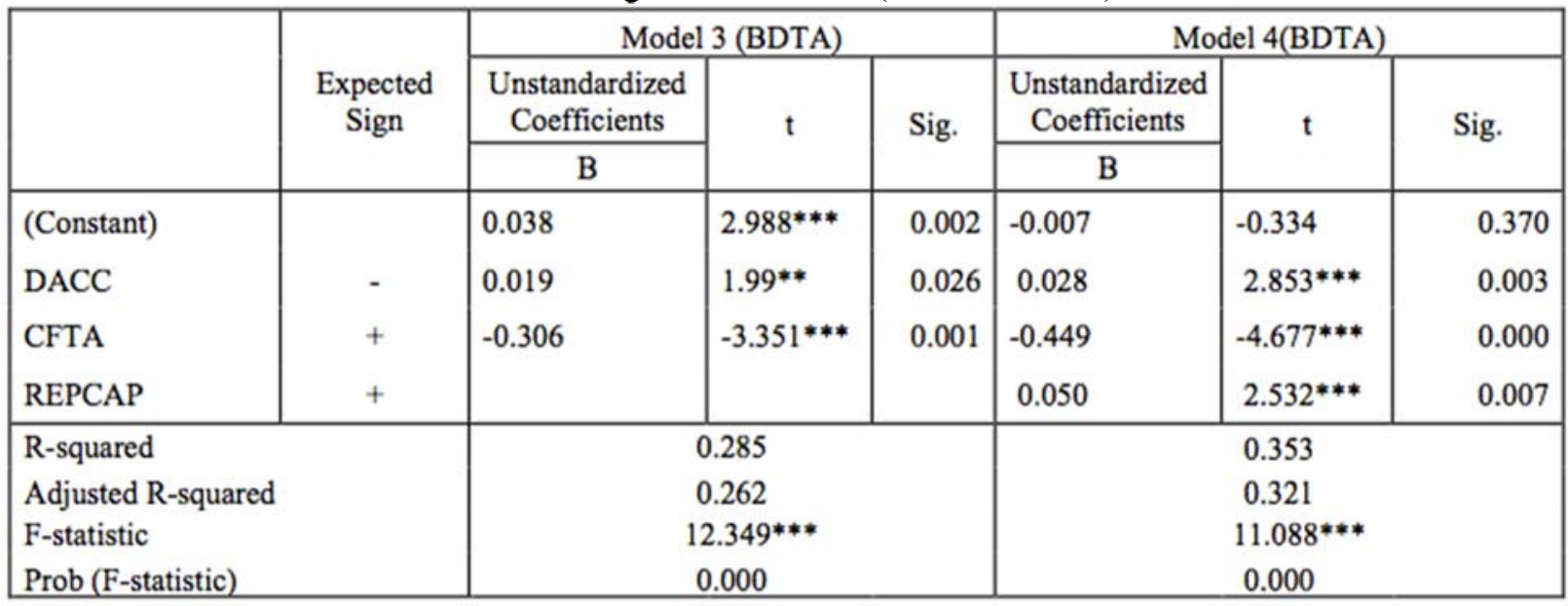

$* * *$ Significant at the 0.01 level

** Significant at the 0.05 level

* Significant at the 0.10 level

BDTA is Bank debt to total assets

DACC is Discretionary accruals

REP is Corporate reputation

REPCAP is Corporate reputation estimates

CFTA is Operating cash flow divided by total assets

Source : Data processed with SPSS 23

\section{RESULTS AND DISCUSSION \\ Earnings Management Practices and Corporate Reputation}

The first regression model is designed to examine the association between earnings management practice and corporate reputation. Hypothesis 1a is tested in order to find the effect of earnings management practice on corporate reputation. Based on the regression result from Table 1, DACC has a negative coefficient and a p-value of 0.004 , which means that the -0.215 coefficient of DACC is significant at the $1 \%$ level. Therefore, it can be concluded from the result that earnings management practice has a significant negative association with corporate reputation. Thus, hypothesis H1a that earnings management practice has a negative association with corporate reputation is accepted.

This finding is in accordance with a previous research finding 6 that earnings management practice decreases corporate reputation. Another study ${ }^{5}$ also pointed out the negative impact of discretionary accounting practice on company value. Therefore, the public will perceive opportunistic earnings management as being damaging to corporate reputation.

There is evidence from the research findings that external parties are able to discern the magnitude of earnings management performed by companies. Therefore, opportunistic earnings management will decrease the public's perceived corporate reputation because externals parties such as investors dislike earnings management practice due to the information asymmetry it creates. Corporate reputation ${ }^{4}$ is a perceptual representation of a company's past actions and future prospects that serves to define its overall appeal, with the results of this research demonstrating that earnings management is perceived as a negative action that can damage corporate reputation.

\section{Corporate Reputation and Corporate Borrowing Capacity}

The second regression model is designed to detect the association between corporate reputation and corporate borrowing capacity. Hypothesis $2 \mathrm{a}$ is tested in order to determine the effect of corporate reputation on corporate borrowing capacity. Based on the regression result from Table 1, REP has a positive coefficient and a pvalue of 0.017 , which means that the 0.029 coefficient of REP is significant at the $5 \%$ level. Therefore, it can be concluded from the result that corporate reputation has a significant positive association with corporate borrowing capacity. Thus, hypothesis H2a that corporate reputation has a positive association with corporate borrowing capacity is accepted.

This finding is in accordance with a previous research finding ${ }^{8}$ that a positive corporate reputation can become collateral for banks to grant loans. Another study ${ }^{7}$ also found a positive association between corporate reputation and corporate borrowing capacity. These findings thus provide evidence that banks will tend to grant higher borrowing capacity to a corporation with a higher reputation.

A good corporate reputation will act as a signal that the company is perceived as a more capable and trustworthy company. The perceived corporate reputation can act as collateral for companies wishing to borrow. 
Therefore, banks and creditors will grant a higher borrowing capacity to a company with a higher reputation as they will deem such a company to be more capable with regard to repaying its loans and maintaining its corporate reputation.

\section{Earnings Management Practice and Corporate Borrowing Capacity}

The third regression model is designed to identify the association between earnings management practice and corporate borrowing capacity. Hypothesis $3 \mathrm{a}$ is tested in order to determine the effect of earnings management practice on corporate borrowing capacity. Based on the regression result from Table 2, DACC has a positive coefficient and a p-value of 0.026 , which means that the 0.019 coefficient of DACC is significant at the $5 \%$ level. Therefore, it can be concluded from the result that earnings management has a significant positive association with corporate borrowing capacity. Thus, hypothesis H3a that earnings management practice has a negative association with corporate borrowing capacity is rejected.

This result supports the previous finding ${ }^{11}$ that bank monitoring is negatively associated with earnings management behavior. A bank with less monitoring over borrowers may give rise to undetected earnings management behavior. Another study ${ }^{9}$ also suggested that firms may be able to move toward their expected credit ratings by engaging in earnings management. Therefore, under this circumstance, earnings management practice has a significantly positive association with corporate borrowing capacity.

The findings show that banks may miss the earnings management practice performed by a company. Banks using a firm's financial reports as the basis for granting loans can be affected by the existence of earnings management in the financial reports and increase the corporate borrowing capacity as a result without having sensed any manipulation of the firm's reported earnings.

\section{Corporate Reputation Estimate and Corporate Borrowing Capacity}

The fourth regression model is designed to detect the association between earnings management practice and corporate borrowing capacity. Hypothesis $4 \mathrm{a}$ is tested in order to determine the effect of earnings management practice on corporate borrowing capacity. REPCAP is an estimated value of corporate reputation under the first model. Based on the regression result from Table 2, REPCAP has a positive coefficient and a p-value of 0.006, thus indicating that the 0.029 coefficient of REPCAP is significant at the $1 \%$ level. Therefore, REPCAP has a significant positive association with borrowing capacity. Thus, from the result it can be concluded that corporate reputation estimate has a significant positive association with corporate borrowing capacity.

The significant negative association of DACC or earnings management with corporate reputation means that earnings management decreases corporate reputation, and the positive association between corporate reputation estimate and corporate borrowing capacity shows that earnings management practice has an indirect effect on corporate borrowing capacity through corporate reputation. Therefore, hypothesis H4a stating that earnings management practice has a negative association with corporate borrowing capacity through corporate reputation is accepted.

This finding is in accordance with a previous research finding ${ }^{6}$ that earnings management practice decreases corporate reputation. Another previous study ${ }^{8}$ pointed out that a positive corporate reputation can be used as collateral by banks to grant loans, while another research finding ${ }^{7}$ also pointed out the positive association between corporate reputation and corporate borrowing capacity.

There are thus three factors that affect corporate borrowing capacity ${ }^{12}$. The first is the factor of relationship, which concerns the historical borrowing relationship between the bank and the company. The second factor concerns the company's financial report as a quantitative measure of the business profile, management, and financial condition of the company. The third factor is collateral, which is something that can be used as assurance by the bank that the company would not engage in opportunistic behavior after having received a loan.

\section{CONCLUSION}

The main purpose of this research was to provide empirical evidence regarding the effect of earnings management on corporate reputation and corporate borrowing capacity. This research was also conducted to determine the effect of corporate reputation on borrowing capacity and the two-stage effect of earnings management on corporate borrowing capacity through corporate reputation.

Based on the research findings, it can be concluded that earnings management practice is negatively associated with corporate reputation, and corporate reputation is positively associated with corporate borrowing capacity. This research has also found that the magnitude of earnings management practice has a marginally significant negative association with corporate borrowing capacity from the two-stage relationship through corporate reputation.

There are some limitations in this research: (1) The observations in this research comprise the pooled data of all industries listed on the Indonesian Stock Exchange in the period 2012-2013 and rated in Frontier Consulting 
Group's Corporate Image Award in 2013 and 2014 (excluding the financial services industry); (2) The observations in this research are limited to only a two-year period covering the years 2012 and 2013; (3) There is a limitation in the measurement of earnings management by using discretionary accruals under the Modified Jones Model as a proxy without taking account of the other method in finding the discretionary accruals or real activity earnings management; (4) There is a limitation in the measurement of corporate reputation based on the Frontier Consulting Group's Corporate Image Award, which uses a broad set of criteria besides earnings management to determine corporate reputation.

There are several implications of this study. Since there are many other factors that determine corporate reputation, it is not enough for banks or creditors to consider only corporate reputation when looking to shield themselves from earnings management practice on the part of the debtors. It is thus recommended for banks and creditors to enforce more monitoring over the corporate or debtor's earnings report in order to detect any opportunistic earnings management performed by the management in order to avoid any misjudgment in loan approval caused by earnings management.

External parties such as investors are aware of and concerned about earnings management. The existence of earnings management will lead to a lower corporate reputation as perceived by external parties, and corporate reputation can also serve as one factor of consideration for banks to grant loans. From those findings, it is recommended for companies to act more ethically in reporting their earnings. The magnitude of their earnings management will decrease the corporate reputation, while there is also the potential for it to reduce their borrowing capacity. If corporate reputation is taken into account, any decrease in this may not be favorable for a company's future. Therefore, in order to maintain their reputation, companies should behave ethically in order to avoid earning a bad perception among external parties.

There are some recommendations for future research regarding this topic: (1) Future research can extend the number of observations and research period to improve the quality of research findings and show the association between earnings management practice, corporate reputation, and corporate borrowing capacity; (2) Future studies could increase the length of the research period to improve the quality of the research regression model to show the association between each research variable; (3) Future research could use real activity earnings management as one of the variables to represent earnings management practice; and (4) Future research could use another reputation survey from a surveyor such as Forbes to determine corporate reputation.

\section{REFERENCES}

[1] W. R Scott. Financial Accounting Theory, 7th Edition. Pearson, Toronto (2015).

[2] C. W. L Hill, G. R. Jones. Strategic Management, 10th Edition. Cengage Learning, Boston (2013).

[3] R. L. Watts, J. L. Zimmerman. Towards a positive theory of the determination of accounting standards. The Accounting Review, 53(1)(1978) 112-134.

[4] C. J. Fombrun, N. A. Gardberg, M. L. Barnett. Opportunity platforms and safety nets: Corporate citizenship and reputational risk. Business and Society Review, 105(1)(2000) 85-106.

[5] S. Roychowdhury. Earnings management through real activities manipulation. Journal of Accounting and Economics, 42(3)(2006) 160177.

[6] J. Martínez-Ferrero, S. Banerjee, I. M. García-Sánchez. Corporate social responsibility as a strategic shield against costs of earnings management practices. Journal of Business Ethics, 133(2)(2016) 305-324.

[7] A. Pebriani, A. A. Hermawan. Corporate reputation, family ownership, political relationship, and borrowing capacity. Proceeding of Simposium Nasional Akuntansi XVIII, Medan, Indonesia, (2015).

[8] M. Loumioti. The use of intangible assets as loan collateral. Working Paper, SSRN (2012).

[9] W. Alissa, S. B. Bonsall IV, K. Koharki, M.W. Penn Jr. Firms' use of accounting discretion to influence their credit ratings. Journal of Accounting and Economics, 55(2-3)(2013) 129-147.

[10] Z. Bodie, A. Kane, A. J. Marcus. Investment, 10th Edition. McGraw-Hill, New York (2009).

[11] S. Ahn, W. Choi. The role of bank monitoring in corporate governance: Evidence from borrowers' earnings management behavior. Journal of Banking and Finance, 33(2)(2008) 425-434.

[12] H Uchida. What do banks evaluate when they screen borrowers? Soft information, hard information, and collateral. Journal of Financial Services Research, 40(1-2)(2011) 29-48. 